\title{
Analiza teorije Waltera Bauera o razvoju ranoga kršćanstva u Maloj Aziji
}

\author{
Ivan Bodrožić*, Marko Marina**
}

\begin{abstract}
Sažetak
Autori u članku analiziraju teoriju Waltera Bauera o početcima kršćanstva u Maloj Aziji. Prvenstveno temeljem analize primarnih izvora, ali i suvremene stručne literature utvrđuju se Bauerove pogreške u argumentiranju. Pri tome se posebno kritički obrađuje Bauerova teza o gnosticizmu kao o struji kršćanstva koja je na području Male Azije tijekom prva dva stoljeća bila najzastupljenija. Zaključuje se da je riječ o pogrešnom pristupu u interpretaciji izvora te prema tomu i o pogrešnoj rekonstrukciji razvoja ranog kršćanstva na spomenutom području.

Ključne riječi: Walter Bauer, rano kršćanstvo, gnosticizam, pravovjerna $\mathrm{Cr}$ kva, Mala Azija
\end{abstract}

\section{Uvod}

Walter Bauer bio je njemački teolog i povjesničar ranog kršćanstva. Iz njegove duge akademske karijere, tijekom koje je predavao na sveučilištima u Wrocławu i Göttingenu, u krugovima se stručnjaka i danas pamti njegov grčko-engleski leksikon Novog zavjeta i ostale ranokršćanske literature (Hartog, 2015, 1). No, djelo koje mu je donijelo svjetsku popularnost tiče se izravno povijesti ranog kršćanstva, a prvi puta je objavljeno 1934. godine pod naslovom Rechtgläubigkeit und Ketzerei im ältesten Christentum. ${ }^{1}$ Jedan je od ciljeva članka izložiti kritičkom pogledu i pregledu Bauerove argumente u vezi s razvitkom ranog kršćanstva u Maloj Aziji. Nadalje, putem analize spomenute teme, pokušat će se pojasniti odnosi gnosticizma i pravovjerne Crkve na području Male Azije. Odmah u uvodu samog članka valja postaviti istraživačko pitanje: Koliku bi važnost povjesničari, sociolozi, teolozi i drugi zainteresirani stručnjaci trebali pridavati Bauerovim argumentima?

* Izv. prof. dr. sc. Ivan Bodrožić, Katolički bogoslovni fakultet. Adresa: Vlaška ulica 38, 10000 Zagreb, Hrvatska. E-pošta: ivan.bodrozic@gmail.com

** Marko Marina, mag. hist. i mag. educ. hist.

1 U članku se koristi engleski prijevod te knjige prvi put objavljen 1971. pod naslovom Orthodoxy and Heresy In Earliest Christianity. 


\section{Teorija Waltera Bauera: kršćanstvo ili kršćanstva?}

Prema Walteru Baueru tradicionalna priča o nastanku pravovjerne Crkve bila je pogrešna. Nakon Isusova života nije prvotno postojala pravovjerna struja koja bi se potom razvila u čvrstu zajednicu, da bi zatim nastale razne hereze sa svojom reinterpretacijom prvotne poruke Isusa iz Nazareta. Time je Bauer potpuno zanijekao događaj Isusa Krista, napose uskrsnuće, svodeći kršćanstvo samo na poruku koja se na različitim mjestima različito tumačila. Rano kršćanstvo nije obilježeno vjerodostojnim svjedočanstvom o Isusu koje šire apostoli i njihov krug kao radosnu vijest, te naknadim nastankom nekih drugih struja koje u odnosu na apostolsko svjedočanstvo i poruku imaju nešto sasvim drugo. Za Bauera crkveni autori nisu relevantni izvori jer nastupaju polemički sa strategijskim ciljem pobjede $\mathrm{u}$ povijesnom nadmetanju, ${ }^{2}$ pa je istovremeno potrebno u potpunosti promijeniti paradigmu razmišljanja o ranom kršćanstvu. Uslijed takve vrste rezoniranja jedini je mogući zaključak da tijekom prva tri stoljeća ne možemo govoriti o jednom kršćanstvu, nego o više različitih kršćanstava.

Bauerova je metodologija u biti geografska: na temelju analize četiriju centara (Egipat, Edessa, Mala Azija i Rim) Bauer izvodi svoje zaključke. U Edessi, ${ }^{3}$ Egiptu i Maloj Aziji ${ }^{4}$ nisu prvotno bili sljedbenici pravovjerne struje, nego različite heretičke skupine, što bi zapravo značilo da je terminologija hereza-pravovjerje pogrešna s obzirom na to da hereza pretpostavlja odvajanje od pr(a)vovjerne struje unutar Crkve (Bauer, 1971, 8, 59, 79). Rim je pak bastion pravovjerja odgovoran za konačan ishod cijele utrke. Na temelju Klementova pisma Crkvi u Korintu Bauer zaključuje kako je Rimska crkva nametnula svojom političkom i teološkom snagom drugim crkvama svoju vrstu kršćanstva kao normativ, te da se ista vrsta kasnije putem crkvenih sabora i regulativa uspostavi kao Crkva kakvu danas poznajemo. Bauer tako ističe: »Rim ne djeluje onda kada je ispunjen ljubavlju ili kada su važna vjerska pitanja dovedena u opasnost, nego onda kada vidi priliku za širenje svojeg utjecaja « (Bauer, 1971, 97-98). Taj je kratki pregled Bauerove teze samo početak dublje analize, pri čemu će se naravno koristiti izvorni Bauerovi zaključci. U ovom radu namjera je propitati jednu „geografsku postaju“ Bauerova argumentacijskog puta. Riječ je o Maloj Aziji, jer je njemački teolog pretpostavljao da je upravo ondje postojao gnosticizam, religijski fenomen od posebnog interesa autorima ovoga članka, kao prva forma kršćanstva. ${ }^{5}$

Prije toga smatramo razumnim uputiti čitatelja u historijsku recepciju Bauerova rada. Naime, nakon što je knjiga objavljena u engleskom prijevodu 1971.,

2 Bauer se posebno okomio na Euzebija Cezarejskog te je njegovo svjedočanstvo o najranijoj povijesti crkve uglavnom odbacio na nekoliko mjesta u svojoj knjizi. Tako primjerice negira Euzebijevu rekonstrukciju povijesti ranog kršćanstva u Edessi (Bauer, 1971, 3). Osim toga, smatra povijesno nepouzdanim i Euzebijevu listu aleksandrijskih biskupa (Bauer, 1971, 45).

3 Antički grad u sjevernoj Mezopotamiji. Danas se na tom mjestu nalazi grad Şanlıurfa (Turska).

4 Poluotok koji se još naziva i Anatolijom, a danas se ondje nalaze dvije suvremene države: Turska i Armenija.

5 Rano kršćanstvo u Egiptu bilo je također, prema Baueru, izvorno gnostičko. Međutim, zbog opsega članka valja se fokusirati samo na Malu Aziju. 
njezina se popularnost počela strelovito širiti. Gotovo da ne postoji ni jedna suvremena ranokršćanska studija s anglosaksonskog područja u kojoj se ne spominje utjecaj Bauera i njegovih teza (Hartog, 2015, 10). Bart Ehrman tako Bauerovu studiju naziva »najvažnijom knjigom o povijesti ranog kršćanstva u posljednjem stoljeću « (Ehrman, 2003, 173). Na drugom mjestu isti autor Bauerov rad karakterizira kao vjerojatno »najznačajniji suvremeni rad o ranom kršćanstvu « (Ehrman, 1993, 7). Jeffrey Bingham govori o Bauerovoj knjizi kao o »nositelju promjene paradigme « (Bingham, 2006, 50). James Robinson i Helmut Koester u svojoj knjizi Trajectories through Early Christianity (1971.), nude svesrdnu podršku Baeurovoj tezi te iznose mišljenje da su kategorije „pravovjerje“ i „hereza“ sasvim neprikladne jer ne uspijevaju rekonstruirati ranokršćansku različitost na ispravan način (Robinson i Koester, 2006, 270). Recentne povijesno-teološke studije o Novom zavjetu također metodološki prihvaćaju Bauerovu tezu o heterogenosti ranokršćanskog perioda. ${ }^{6}$ Paradoksalna je to činjenica kada se uzme u obzir da se Bauer u svojem radu uopće nije doticao novozavjetnih dokumenata smatrajući ih neproduktivnima jer se oko njih ne može postići nikakav konsenzus, pa stoga ne mogu služiti kao temelj od kojeg valja krenuti u rekonstrukciju povijesti ranog kršćanstva (Bauer, 1971, 15).

S druge pak strane, postoje određeni autori koji su svaki u svoje vrijeme krenuli u opovrgavanje njegovih teza. ${ }^{7}$ Prva velika kritika Bauerova rada Turnerovo je djelo The Pattern of Christian Truth (1954.), u kojem engleski teolog nastoji raskrinkati sve greške Bauerove argumentacije. Turner zaključuje da ne postoji ništa što bi poduprlo Bauerovu rekonstrukciju ranog kršćanstva na području Male Azije (Turner, 2004, 63). Vjerojatno najznačajnija kritika Waltera Bauera kada je posrijedi područje Male Azije dolazi iz pera američkog povjesničara Tomasa A. Robinsona. U knjizi The Bauer Thesis Examined Robinson ističe kako je Mala Azija jedino područje u kojem ima dovoljno izvora za kredibilnu rekonstrukciju povijesti ranog kršćanstva. Upravo ondje Robinson pronalazi brojne greške u argumentaciji i zaključivanju Waltera Bauera te zaključuje: »Bauerova rekonstrukcija ranokršćanske Crkve u Maloj Aziji upućuje na jednu ozbiljnu grešku u njegovoj tezi. Pogreška Bauerove teze u Maloj Aziji nije samo iznimka u odnosu na njegove rekonstrukcije drugih područja. Greška u tezi na području koje je jedino dovoljno bogato izvorima da bi se moglo testirati baca veliku sumnju na ostala područja Bauerova istraživanja« (Robinson, 1988, 204). Godine 2006. objavljen je i članak Paula Trebilca Christian Communities in Western Asia Minor into the Early Second Century: Ignatius and Others as Witnesses against Bauer. U njemu

6 Primjerice James Dunn, koji u svojem monumentalnom djelu objavljenom 2006. pod naslovom Unity and Diversity in the New Testament: An Inquiry into the Character of Earliest Christianity načelno prihvaća Bauerovu tezu o snažnoj heterogenosti ranog kršćanstva. Ehrmanova knjiga prvi put objavljena 1997. naslova The New Testament: A Historical Introduction to the Early Christian Writings također slijedi Bauerovu argumentaciju. Ista je knjiga dio obvezatne literature na mnogim sveučilištima u Sjedinjenim Američkim Državama, a i najprodavanija je knjiga te tematike u toj državi. U ovom se članku koristi drugo izdanje, objavljeno 2000. godine.

7 Zbog opsega članka zadržat ćemo se samo na najvažnijim radovima koji se posebno tiču područja Male Azije. 
Trebilco pomno analizira Bauerove teze o Maloj Aziji te ističe kako se s pravom treba govoriti o vremenskom primatu pravovjerne Crkve ondje: »Korijeni kasnijeg pravovjerja se pronalaze ovdje (u Maloj Aziji, op. a.). Pravovjerje se ne treba smatrati kasnijim izumom onih na vlasti ili nečim što je odlučeno isključivo politikom. Pravovjerje vuče svoje korijene iz najranijeg razdoblja (Trebilco 2006, 43). Trebilco tako zaključuje: »Bauerova teza ne može opstati pod teretom dokaza kada je posrijedi situacija u Maloj Aziji. [...] Ono što Bauer naziva „herezom“ nije ni najranija ni najdominantnija forma kršćanske vjere (Trebilco, 2006, 43).

Prvenstveno analiziranjem izvora nastojat će se ukazati, na primjeru ranokršćanske zajednice u Maloj Aziji, nepostojanje dostatnih razloga za radikalnom promjenom paradigme. Naime, smatramo da se uzroci masovne popularnosti Bauerove teze na anglosaksonskom području (pri tome se misli na Englesku i Sjedinjene Američke Države) ne trebaju tražiti u internoj potrebi za radikalnom reinterpretacijom postojećih izvora, nego u prevladavajućem duhu vremena. Phillip Jenkins dobro primjećuje da su postmodernizam i feminizam imali odlučujući utjecaj na promjenu paradigme u proučavanju ranog kršćanstva: »Od 1960-ih godina marginalni su se pokreti odjednom vratili kao esencijalni element u razumijevanju kršćanskih početaka« (Jenkins, 2001, 15). Tržištem su polako zavladale knjige koje otkrivaju „novog Isusa“ ili „alternativne forme kršćanstva“. 8 Pravovjerna je Crkva u pravilu prikazana kao persona non grata, koja svojim hijerarhijskim pravilima i strogom disciplinom guši čovjekovu istinsku duhovnost. Knjige-nositelji takvih ideja govore čitateljima upravo ono što oni želi čuti, a ne ono što bi nužno bila povijesna istina (Jenkins, 2001,16). ${ }^{9}$

\section{Bauerova teza o kršćanstvu u Maloj Aziji}

Prelazeći na samo središte argumenta valja poći od Ignacija Antiohijskog, jer se i Bauer služio njegovim spisima za svoje zaključke. Ignacije Antiohijski bio je jedan od apostolskih otaca, učenik samih apostola i jedan od najvažnijih crkvenih autoriteta ranog kršćanstva. Smatra se da je oko 107. godine doveden u Rim i ubijen. ${ }^{10}$ Dok su ga rimski vojnici vodili kroz Malu Aziju put Rima, napisao je sedam pisama: Efežanima iz grada Efeza (zapadna obala Male Azije, današnja Turska), Magnežanima iz grada Magnezija na Sipilu (današnja Turska), Tralijanima iz grada Tralesa (današnja Turska), Rimljanima, Filadelfijanima (današnji

8 Bart Ehrman tako jednu od svojih knjiga naslovljava Lost Christianities: The Battles for Scripture and the Faiths We Never Knew.

9 Valja istaknuti da u moru recentnih knjiga koje pretendiraju objasniti povijest ranog kršćanstva nisu sve jednako kvalitetne. Postoji raspon od onih koje karakterizira potpuna lišenost znanstvenog pristupa u proučavanju povijesti (poput knjige Dana Browna Da Vincijev kod) do onih napisanih od renomiranih povjesničara i teologa (poput već spomenutog Barta Ehrmana), koji pristupaju problematici ranog kršćanstva na znanstveni način. Njihovi zaključci, koji su u skladu s glavnim karakteristikama Bauerove teorije, otvaraju prostor za ozbiljne analize i rasprave.

10 Euzebije u svojim spisima navodi kako je Ignacije ubijen u 10. godini vladavine cara Trajana, što bi bila 107. godina (Euzebije, 1989, 3.36). 
grad Alaşehir u zapadnom dijelu Turske), Smirnjanima iz grada Smirne (današnji Izmir zapadna Turska) i Polikarpu — o kojem će kasnije biti više govora. ${ }^{11}$ Bauer gradi svoju tezu o Maloj Aziji na temelju nekoliko argumenata. Prvenstveno je vjerovao da je Ignacije pisao crkvama u Maloj Aziji kako bi ih upozorio na veliku opasnost koja je vladala ondje: gnosticizam (Bauer 1971, 63). Za Bauera je prvotna verzija kršćanstva u Maloj Aziji bila ona gnostička.

Međutim, detaljna analiza Ignacijevih pisama upućuje na sasvim suprotan zaključak. Primjerice u Poslanici Magnežanima Ignacije zapisuje: »Ne dajte se zavesti krivim naucima ni drevnim beskorisnim pričama. Ako još živimo po židovsku, priznajemo da nismo primili milost. Sveti su proroci živjeli prema Isusu Kristu. Zato su bili progonjeni jer bijahu njegovom milošću nadahnuti da nevjerne uvjere kako je jedan Bog koji se očitova po Isusu Kristu, svojemu Sinu, koji je njegova Riječ potekla iz šutnje i koji je njemu, koji ga posla, u svemu omilio« (Ignacije, 2010, 56).

Analizirajući taj tekst, nije moguće izbjeći zaključak kako Ignacije zapravo upozorava na judaizante - dio onih kršćana koji su se držali židovskih ceremonijalnih zakona, obreda i službi u hramu, smatrajući Mojsijev zakon neizostavnim u svim njegovim detaljima. Iako je, disciplinski gledano, to pitanje riješeno na apostolskom saboru u Jeruzalemu, čini se kako se određeni židovski krugovi nisu mirili s takvim odlukama te su nastavili djelovati po vlastitom nahođenju. ${ }^{12}$ Zanimljivo je, međutim, kako autor Otkrivenja u pismu crkvi u Filadelfiji ne spominje judaizante (Otkrivenje 3, 7-13) dok ih sam Ignacije spominje, kako u Magneziji, tako i u Filadelfiji (Ignacije, 2010, 74) Najvjerojatnija je rekonstrukcija povijesnih događaja, ispravno primjećuju Kruger i Kostenberg, da su se judaizanti ondje pojavili između pisanja Otkrivenja i Ignacijeve poslanice (Kostenberg i Kruger, 2010, 43).

Ignacije se pak u Tralesu svojom poslanicom suprotstavlja doketističkomu nauku ${ }^{13}$ svjedočeći bitne povijesne činjenice o Isusu: »Stoga, začepite svoje uši kada vam netko govori bez Isusa Krista iz roda Davidova, Marijina sina, koji je

11 Dok su ga kao uznika vojnici vodili od Antiohije do zapadne obale Male Azije, imao je prigodu upoznati predstavnike zajednice Filadelfijana. Kad su nakon toga otputovali prema Smirni, tamo je upoznao tamošnjeg biskupa Polikarpa. Odatle je napisao pisma Efežanima, Magnežanima, Tralijanima te Crkvi u Rimu. Nakon toga je iz Troade napisao i pisma Filadelfijanima, Smirnjanima i Polikarpu. Detaljnije o njegovu putovanju vidi u: Trebilco, 2006, 19-20.

12 Apostolski sabor u Jeruzalemu bio je prvi povijesni kršćanski sabor kojeg su predvodili apostoli. Vjeruje se kako je održan oko 50. godine. Glavni izvor za taj događaj su Djela apostolska. U konačnici je presuđeno u Pavlovu korist te je Krist stavljen iznad odredbi Mojsijeva zakona. Obraćenici iz poganstva nisu morali proći ceremonijalne židovske obrede, nisu trebali biti obrezani i vršiti ostale norme. Bilo je dostatno da prihvate vjeru u Krista, te da se čuvaju određenih čina koji bi mogli iritirati židove: blagovanje mesa žrtvovana idolima, udavljenoga, krvi i bludništva ( $\mathrm{Dj} 15$, 19-21).

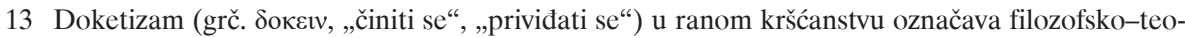
loško uvjerenje kako je Kristovo tijelo bilo samo privid i da je on u biti bio samo duhovno biće. Taj se izraz prvi puta pojavljuje u pismu Serapiona Antiohijskog crkvi Rososa povodom čitanja gnostičkog evanđelja po Petru. O etimologiji i značenju riječi „doketizam“ vidi više u: González, $2015,46$. 
stvarno bio rođen, jeo i pio, stvarno bio progonjen pod Poncijem Pilatom, stvarno razapet i umro naočigled nebesnika, zemnika i podzemnika « (Ignacije, 2010, 62). Uz to, Ignacije u kasnijem poglavlju jasno i spominje riječ „doketi“ i njihove opasne zablude kojih se kršćani moraju kloniti (Ignacije, 2010, 62). Bauer prihvaća doketizam kao predmet Ignacijeva interesa i pobijanja, ali zaključuje, sasvim neutemeljeno, kako je to dostatna kategorija za postojanje gnosticizma (Bauer, 1971, 92). Nasuprot njemu, Christoph Markschies, unatoč tomu što gnosticizam vidi kao jednu vrstu heleniziranog kršćanstva, smatra kako doketizam ne može biti dostatna varijabla u detektiranju gnosticizma: »Ne postoje izvori iz 1. stoljeća koji bi korespondirali s gnostičkim pokretom « (Markschies, 2003, 68). Uz to, ne smije se zaboraviti da gnosticizam predstavlja religijski fenomen sa specifičnim teološkim sustavom u čijem je temelju antikozmički dualizam, odnosno snažni lom između Boga Starog i Boga Novog zavjeta te ideja tajnog znanja kao krucijalnog elementa u spasenju čovjekove duše (Petrement, 1990, 9).

Nadalje, doketizam je posljedica helenističke reakcije na kršćansku vjeru u Kristovo utjelovljenje. Filozofiji platonizma je, kao najdominantnijoj filozofskoj struji helenističkog svijeta, bilo nepojmljivo, pa čak i nedostojno, da bi se neko božansko biće moglo utjeloviti. Naime, prema takvoj filozofiji, duhovna je sfera bila divinizirana, duša je ona istinska supstancija, a tijelo je shvaćano kao tamnica duše. Duša je u tijelu kao posljedica kazne (Platon, 2006, 52) ili pak kao posljedica neke nužnosti. ${ }^{14}$ Zacijelo su, stoga, određeni krugovi obraćenika iz poganstva, čuvši navještaj o Isusovu utjelovljenju, pribjegli onomu što je njima bilo najpoznatije, pa su zaključili kako je Isus zapravo bio duhovno biće, bez pravog tijela. A na primjedbe onih koji su pitali kako onda razumjeti apostolska svjedočanstva o njegovoj tjelesnoj pojavnosti (rođenju, muci i smrti), odgovarali su da je njegova tjelesnost bila samo privid, obmana. Doketizam stoga možemo jednostavno nazvati primjerom helenističke reinterpretacije ideje Kristova utjelovljenja. Ono što je posebno zanimljivo u takvoj elementarnoj ocjeni doketizma tiče se vremena njegova nastanka. Ako je on kasnija pojava, prilagodba na nešto što postoji, to bi onda značilo da je vjera u Kristovo utjelovljenje bila prvotni sadržaj ranih kršćanskih vjeroispovijesti, sukladno novozavjetnim svjedočanstvima, a s čime se slažu mnogi autori koji su studiozno propitivali to razdoblje. ${ }^{15}$ Imajući to na umu, Bauerova ideja o prvim kršćanima kao krivovjercima u Maloj Aziji na prvoj je postaji analize pobijena. Međutim, nije to jedini argument kojeg Bauer nudi u svojoj viziji razvitka ranokršćanskih zajednica na tom području.

14 Ne smije se miješati platonizam s gnosticizmom. Iako imaju dodirnih točaka, gnostički je dualizam drukčijeg karaktera. Kod gnostika je Demijurg, odnosno Bog Starog zavjeta okarakteriziran negativnim epitetima i on stvara svijet takvim kakvim ga stvara - tamnicom i zatvorom, a kod Platona Demijurg je ipak pokušao stvoriti najbolji mogući svijet. Vidi više u: Lewis, 2013, 157.

15 Ta se teza još naziva i tezom „visoke kristologije“ i u suprotnosti je s teorijom koja smatra da su kršćani tek nakon nekoliko generacija i desetljeća počeli Isusu pripisivati božanske atribute. Vidi primjerice: Hurtado, 2003, 109; Bird i dr., 2014, 52-61; Gathercole, 2006. 


\subsection{Sedam crkava Otkrivenja}

Bauerov sljedeći argument temelji se na maloazijskim crkvama kojima autor Knjige otkrivenja i Ignacije nisu pisali. ${ }^{16}$ Autor Otkrivenja u drugom i trećem poglavlju svojeg rada spominje crkve u Efezu, Smirni, Pergamu, Tijatiri, Filadelfiji, Laodikeji i Sardu. Bauer vidi kao posebno problematičnu činjenicu da autor Otkrivenja ne spominje druge crkvene zajednice, primjerice poput one $\mathrm{u}$ Kolosi, ${ }^{17}$ s obzirom na to da iz Pavlove poslanice Korinćanima znamo da je ondje otprije postojala zajednica kršćana. Osim toga, postojala je i zajednica kršćana u Hierapolisu, ali toj crkvi ne pišu ni Ignacije ni Ivan — kojeg Bauer smatra autorom Otkrivenja. Njegov je zaključak sljedeći: »Ivan je odabrao najprominentnije zajednice iz tog područja koje su mu dale prostora da zaključi kako bi on svoj utjecaj mogao ondje prenijeti« (Bauer, 1971, 78). Drugim riječima, kršćanske zajednice u Hierapolisu ili Kolosi zapravo su kršćanske zajednice koje stoje u suprotnosti s pravovjernom strujom. Smatramo primjerenim zaključiti kako je tu riječ o primjeru par excellance klasične logičke pogreške u zaključivanju zvane dokaz iz šutnje (lat. argumentum ex silentio), koja nažalost čini veći dio Bauerova rada.

Naime, to što Ivan ili Ignacije ne pišu pisma spomenutim crkvama ne može biti temelj za zaključak da je ondje vladalo krivovjerje. Osim toga, postoje i druga moguća objašnjenja. Primjerice, crkva u Kolosi u ranim je stoljećima zasigurno bila zasjenjena onom u Laodikeji $(17 \mathrm{~km})$, s obzirom na to da je riječ o jednom od najvažnijih gradova tog područja (Trebilco, 2006, 24). Uz to, rimski kroničar Tacit spominje kako je Laodikeja u velikoj mjeri uništena u potresu (Tacit, 2006, 536). Doduše, ne spominje Kolose, ali vrlo je vjerojatno da je i taj grad bio oštećen s obzirom na geografsku blizinu sa samom Laodikejom. Moguće je da se mali grad poput Kolosa nije uspio oporaviti u vrijeme kada Ignacije i Ivan pišu svoja djela. Bauerovo teoretiziranje kako dvoje autora namjerno ne pišu Kološanima jer znaju da su gnostici ondje u većini jednostavno ne može proći kritičku analizu izvora.

Što s Bauerovim tvrdnjama o Hierapolisu? Iz izvora saznajemo da je ondje početkom 2. stoljeća biskup bio Papija (Eusebius, 1981, 195). Euzebije nas također izvještava, pozivajući se na Ireneja Lionskog, da je Papija, kao Ivanov učenik i Polikarpov suradnik, napisao pet knjiga pod naslovom Tumačenja govora Gospodnjih (Eusebius, 1981, 202) ${ }^{18}$ Euzebije doduše sumnja da je Papija zaista

16 Knjiga Otkrivenja posljednja je kanonska knjiga Novog zavjeta. Njezino se autorstvo tradicionalno pripisuje apostolu Ivanu te se smatra kako je napisana negdje pri samom raju 1. stoljeća. Autorstvo Otkrivenja još je uvijek dio rasprave znanstvenika. S jedne strane postoje oni koji se slažu s crkvenom tradicijom, a drugi zbog određenih lingvističkih i historijskih zamjerki idu putem druge opcije uvjereni kako je autor Otkrivenja bio neki drugi Ivan — vjerojatno učenik i sljedbenik apostola Ivana. Vidi više u: Harrington, 1993, 459-460; Ehrman, 2000, 431-434.

17 Grad Kolose drevni je grad u Frigiji (današnja Turska) smješten otprilike 17 kilometara iznad Laodikeje. Točna lokacija grada do danas nije otkrivena.

18 Knjige se nažalost nisu očuvale, ali posjedujemo nekolicinu fragmentarnih citata Papije kod drugih autora (najpoznatiji Euzebije). O Papiji kao izvoru vidi više u: Bauckham, 2006, 14-15. 
bio živ svjedok apostola Ivana, ali napominje da su njegove riječi oslikavale vjeru onih koji su pristajali uz apostole (Eusebius, 1981, 203). Možda je najznačajniji u kontekstu povijesti ranog kršćanstva Papijin citat o autorstvu kanonskih evanđelja. Papija predstavlja najranije svjedočanstvo o Marku i Mateju kao autorima evanđelja (Eusebius, 1981, 206). Iz svega što znamo o Papiji teško je izbjeći zaključak da je riječ o crkvenom autoru koji nije mogao biti dio gnostičke struje. Pavić i Tenšek ističu kako Papiju »treba smatrati predstavnikom judeokršćanske teologije « (Pavić i Tenšek, 1993, 25).

Valja također i napomenuti da ne postoji ni jedan gnostički učitelj s kraja 1. stoljeća. ${ }^{19}$ Prihvatimo li čak da je Menander gnostik u punom smislu, ${ }^{20}$ to ne bi bilo dostatno za Bauerov zaključak. Menander je vrlo vjerojatno aktivno djelovao na početku 2. stoljeća, u najboljem slučaju u vrijeme Ignacijevih poslanica (Smith, 2004, 131). Čini se nevjerojatnom teorija prema kojoj je on uspio proširiti svoju sljedbu iz Antiohije, središta u kojem je djelovao, preko cijele Male Azije u samo nekoliko godina. Postavlja se logično pitanje: Ako Menander nije gnostički učitelj odgovoran za širenje gnosticizma preko Male Azije, tko jest? Uslijed svega rečenog, valja zaključiti da je Bauerova rekonstrukcija ranog kršćanstva u Kolosima i Hierapolisu, gdje postulira dominantnost gnostika, naprosto pogrešna.

Nadalje, što je s crkvama kojima samo Ivan piše? Naime, Ignacije piše samo trima zajednicama kojima piše i Ivan: Efežanima, Smirnjanima i Filadelfijanima. Što je s ostale četiri crkve koje se samo kod Ivana spominju? Bauer ima rješenje:

Je li previše tvrditi, na temelju onog što Ignacije kaže i ne kaže, te uzevši u obzir dokaze iz Otkrivenja, da je u pokušaju da proširi krug svog utjecaja, Ignacije zaključio da nema što tražiti u Pergamu, Tijatiri, Sardu i Laodikeji, jer između njih nije postojao nikakav kontakt - ne postoji „biskup“ u službi ondje, upravo zato jer su heretici zadržali, do neke mjere, vodeću ulogu (Bauer, 1971, 93).

19 Crkvena tradicija smatra kako su sve hereze, pa i ona gnostička, inicijalno započele s pojavom Šimuna Čarobnjaka. Prvi, a ujedno i najvažniji izvor su Djela apostolska, koja spominju Šimuna kao čarobnjaka iz Samarije koji je želio ovladati Duhom Svetim i za posjedovanje te moći nudio je novac Petru, što je Petar sa zgražanjem odbio (Dj 8, 9-26). To je jedini izvještaj iz 1. stoljeća i sve što pouzdano znamo o Šimunu. Justin, izvještavajući nakon više od stoljeća, tvrdi kako je Šimun bio iz sela Giton te da ga se zbog njegovih čudesa smatralo Bogom, a putovao je uz suputnicu Helenu, za koju se vjerovalo da je Prva misao proizašla iz Šimuna (Justin, 2012, 48) Nakon Justina, Irenej nas izvještava puno detaljnije o teološkom sustavu samog Šimuna, kojeg se naziva „ocem iznad svih“, koji se pojavljivao kao Sin Židovima, Otac Samaritancima, a Duh Sveti drugim nacijama (Irenaeus, 1997, 679. No, unatoč crkvenoj tradiciji, čini se kako se o Šimunu kao prvom gnostiku ne može govoriti. Izvještaj koji potječe iz njegova vremena opisuje ga samo kao čarobnjaka željnog vladanja nad Duhom Svetim. Svjedočanstva Ireneja i Justina izuzetno su upitna jer dolaze prekasno na vremenskoj tablici i upućuju na razvijanje mitomanijskih priča koje, čini se, nemaju utemeljenja u stvarnosti (vidi više u: Petrement, 1990, 244-246). No ipak se ne može isključiti mogućnost da su određene „informacije“, kako Justin tako i Irenej, preuzeli iz gnostičkih spisa i priča nastalih u međuvremenu.

20 Takav je zaključak također vrlo upitan jer o Menanderovim se učenjima jako malo zna. Justin nas izvještava kako je dolazio iz samaritanskog sela Kapareteje te da je uspio uvjeriti sljedbenike da neće umrijeti (Justin 2012, 49). Irenej nas upućuje u malo dublju priču, doduše reduciranu na jedan paragraf, objašnjavajući kako se Menander smatrao nositeljem čovječanstva koji se bori protiv anđela odgovornih za stvaranje ovog svijeta (Irenaeus 1997, 68). Vidi više u: Smith, 2011, 131. 
Čini se kako je to ipak, parafrazirajući samog Bauera, jedna tvrdnja previše. Naime, postoje razna moguća objašnjenja zašto Ignacije ne piše tim crkvama, a ni jedno od njih se ne tiče krivovjeraca i njihovog vodstva ondje. Uzmimo za primjer grad Sard? Možemo li doista zaključiti da su ondje već koncem 1. st. glavnu riječ vodili krivovjerci? Osim što nemamo niti jednog dokaza za tu tvrdnju, postoji i spis tamošnjeg biskupa Melitona Peri Pasha. Datiran je doduše u sredinu 2. st., ali je jasan pokazatelj postojanja kršćanske zajednica u Sardu, a koja je prema svojoj teologiji pravovjerna. Možemo li, prema postojećem dokumentu, s visokom sigurnošću zaključiti kako je i 50 godina ranije ondje postojala čvrsta pravovjerna struja? Naravno da ne, ali ne postoji nikakav razlog koji bi nas vodio u suprotnom smjeru. Osim toga, kao što Trebilco ističe, ovakav dokument, otkriven nakon objave Bauerove knjige, pokazuje koliko su njegove teorije, većinom temeljene na argumentu iz prešućivanja, nestabilne (Trebilco, 2006, 27).

\subsection{Polikarp i heretici}

Posljednji argumentacijski stup Bauerovih tvrdnji u vezi s ranokršćanskim prostorom Male Azije je Polikarp, biskup u Smirni, tradicionalno, prema Irenejevu svjedočanstvu, smatran učenikom apostola Ivana. Ne samo da Bauer tvrdi kako su gradovi poput Soluna (Grčka) ili Filipa (istočna Makedonija) bili gradovi zahvaćeni herezom, ${ }^{21}$ nego zaključuje da je i sam grad Smirna u kojem je stolovao Polikarp bio grad prepun heretika i hereze. »Neka se nitko zbog položaja ne uzoholi; sve je vjera i ljubav od kojih ništa nije preče « (Ignacije, 2010, 81). Bauer smatra kako se tu pod terminom „položaj“ misli na službu biskupa, te uzimajući u obzir Ignacijevu poslanicu Polikarpu u kojoj čitamo: »Čuvaj svoj položaj (topos) svom tjelesnom i duhovnom brigom «(Ignacije, 2010, 85), zaključuje da je u Smirni u to vrijeme stolovao antibiskup gnostičke provenijencije. Međutim, takav zaključak uopće ne proizlazi iz priloženih činjenica te su i u tom slučaju moguća drukčija objašnjenja zbog kojih Ignacije Polikarpu upućuje takvu vrstu upozorenja (Hartog, 2015, 39). Također, ne postoji ni jedan izvor koji bi potvrđivao da su gnostici u svojim zajednicama uopće imali službu biskupa. U daljnjoj argumentaciji svojih tvrdnji Bauer koristi početak Polikarpove poslanice Filipljanima u kojoj piše: »Polikarp i svećenici koji su s njime Crkvi Božjoj koja kao tuđinka boravi u Filipima: izobilovali vam milosrđe i mir od Boga svemogućega i Isusa Krista našega Spasitelja (Polikarp, 2010, 101). Prema Baueru, tu je vidljivo kako su samo neke starješine iz Smirne uz Polikarpa, a druge nisu. Zato Polikarp i naglašava »starješine koji su s njim «. Iz takve pretpostavke zaključuje se da su u Smirni u to vrijeme (početak 2. stoljeća) stolovali antiprezbiteri, vjerojatno gnostičke provenijencije (Bauer, 1971, 69.). Bliža analiza izvora upućuje na sasvim suprotan zaključak.

21 Bauer tako iz činjenice da Polikarp piše crkvi u Filipima, ali ne i crkvi u Solunu zaključuje da su ondje od početka stolovali heretici. Iako u jednom paragrafu priznaje opasnost od argumenta iz tišine, već u sljedećem zaboravlja na opasnost od logičke pogreške te vrste i izjavljuje: »Uključio bih također post-Pavlovsku Makedoniju u ona područja kršćanstva u kojima je vladala dominacija heretika, uz Edessu, Egipat... i Siriju-Edesu gdje je hereza bila od samih početaka« (Bauer, 1971, 69). 
Naime, takva bi rekonstrukcija događaja bila u čistoj suprotnosti s Ignacijevim pismom poslanim Smirnjanima jer ondje Ignacije poziva zajednicu u Smirni da slijedi biskupa, prezbitere i đakone kako bi se uspješno klonili krivovjernih učenja (Ignacije, 2010, 81). Iz tog je pisma vidljivo kako Ignacije gleda na biskupe i crkvenu hijerarhiju u Smirni isključivo kao na svjedoke vjerne apostolskomu nauku, te takav razvoj događaja ruši iz temelja Bauerovu tezu o odnosu mogućeg gnosticizma i pravovjerne crkve u Smirni. Posebno je važna činjenica da Ignacije ne odvaja jedne prezbitere od drugih niti daje naslutiti da postoji ikakav raskol između njih. Svaka suprotna teoretiziranja morala bi prihvatiti pretpostavku o Ignacijevu nerazumijevanju crkvene hijerarhije i mogućih hereza. No, takva pak pretpostavka nema utemeljenja ni u jednom dostupnom izvoru (Robinson, 1985, 94.).

Konačno, Bauer svako neslaganje i mogući sukob u Ignacijevim poslanicama oslikava kao sukob nauka i teologija. Drugim riječima, sva su neslaganja koja vidimo u danim poslanicama dokaz akutne opasnosti od hereze diljem Male Azije (Bauer, 1971, 69.). Na jednom mjestu u svojoj poslanici Efežanima Ignacije ističe:

Neka se nitko ne zavarava: tko nije u zajedništvu žrtvenika, ostaje bez Božjega kruha. Ako molitva dvojice ima toliku snagu, koliku će veću imati molitva biskupa i čitave Crkve! Prema tome, tko ne dolazi na sveti skup, taj se već uzoholio, sam sebe izdvojio i osudio. Ta pisano je: „Bog se oholima protivi“. Stoga da bismo bili Bogu odani, nastojmo ne protiviti se biskupu (Ignacije, 2010, 45).

Iz tog se pasusa dade zaključiti kako se jedna grupa kršćana počela okupljati odvojeno od zbora vjernika i biskupa. Međutim, Bauer iz toga izvlači zaključak kako je zasigurno riječ o hereticima koji su ušli u konflikt s postojećom crkvenom strukturom na doktrinarnoj ili teološkoj razini. Šira analiza Ignacijevih pisama, kao i kontekst razvoja crkvene strukture, upućuje nas u suprotnom smjeru. Naime, Ignacije nailazi na sličan problem i u crkvi u Tralesu, gdje također proziva one koji se okupljaju izvan zajednice i svetišta i ne priznaju važnost biskupa, prezbitera i đakona (Ignacije, 2010, 61).

$\mathrm{O}$ čemu je ovdje zapravo riječ? U pokušaju odgovora na to pitanje ključ se pronalazi u ostatku poslanice Efežanima, gdje Ignacije upozorava tamošnju zajednicu da su obvezni gledati na biskupe kao na samog Gospodina (Ignacije, 2010, 45). Dokazi upućuju na problem unutar zajednice i u tome leži razlog zbog kojeg su se neki opirali biskupima i dovodili u pitanje njihovu važnost i utjecaj. Čini se kako se određeni krugovi nisu željeli pomiriti s takvom tranzicijom i prihvatiti nadležnost biskupa na području cijelog Efeza koji bi se u takvoj tranziciji postavio iznad svih tamošnjih prezbitera i đakona (Trebilco, 2006, 30-31). Bauer svojom interpretacijom u potpunosti promašuje širi kontekst vremena i ulogu Ignacija, koji tijekom strukturalnih tranzicija i razvitaka želi proširiti utjecaj biskupa unutar crkvenih zajednica. ${ }^{22}$ Uostalom, biskupi su bili izravni apostolski

22 Primjerice, prema Ignaciju, da bi euharistija bila valjana, mora biti slavljena ili pod biskupovom kontrolom ili pod kontrolom osobe od posebnog biskupova povjerenja (Ignacije Antiohijski 2010, 81; 45; 51-52). Time se središnji liturgijski događaj smješta pod izravni autoritet biskupa. 
učenici, te su posjedovali ovlasti i dužno znanje prema kojem su mogli rješavati probleme na razini zajednica, pa se onda ne treba čuditi da im Ignacije daje potporu u njihovu djelovanju. Razmatrajući Ignacijeva ekleziološka promišljanja, Pavić i Tenšek napominju kako je upravo Ignacije prvi autor koji koristi termin „katolička Crkva“ (Pavić i Tenšek, 1993, 19). Također, za Ignacija »opća Crkva nije samo mistično tijelo Kristovo vezano s Kristom vjerom i ljubavlju, nego je vidljiva organizacija « (Pavić i Tenšek, 1993, 19). Kako isti autori ispravno primjećuju, za Ignacija je veza »s biskupom po vjeri i posluhu izraz crkvenog jedinstva« (Pavić i Tenšek, 1993, 19). Ignacijeva su promišljanja glede hijerarhijskog ustrojstva Crkve takva da je u svih šest poslanica jasno posvjedočeno kako je tim crkvama na čelu jedan biskup okružen prezbiterijem, tj. skupinom prezbitera te đakonima kao svojim pomoćnicima (Šagi-Bunić, 1976, 103). Konačno, početak 2. stoljeća obilježen je stvaranjem većeg razlikovanja između službe prezbitera i službe biskupa, što je moglo ponegdje stvoriti probleme disciplinske naravi.

\section{Walter Bauer i metodologija argumentiranja}

Za sam kraj analize, a u potrazi za reprezentativnim primjerom metodoloških vratolomija njemačkog teologa, valja otići i malo šire od ambijenta Male Azije. Naime, u nakani da pokaže kako se u Filipima, današnja istočna Makedonija, od samih početaka stabilizirala heretička većina, Bauer na svojevrstan način koristi Polikarpovu poslanicu tamošnjim kršćanima. U njoj Polikarp između ostalog upozorava:

Stoga, napustivši isprazna naklapanja i zablude svjetine, opašite svoje bokove i služite Bogu u strahu i istini vjerujući u onoga koji je Gospodina našega Isusa Krista od mrtvih uskrisio i proslavio te ga smjestio sebi zdesna; njega komu je podložio sve što je na nebesima i na zemlji i komu služi svako živo biće, koji dolazi kao sudac živih i mrtvih i čiju će cijenu krvi Bog tražiti od onih koji u njega ne vjeruju (Polikarp, 2010, 103).

Bauer grčku riječ ton pollon uzima kao statističku varijablu te zaključuje kako je to svojevrstan corpus delicti kojeg nam sam Polikarp nudi u prilog tezi o većinskoj populaciji heretika u Filipima (Bauer, 1971, 73). S jedne strane, novija istraživanja pokazuju kako takvomu diskursu ne treba uzroke tražiti u statističkim varijablama i broju heretika. Riječima Rodneya Deckera: »Intenzitet retorike ne korespondira nužno s bilo kakvim procjenama numeričke dominacije. [...] Potencijalna opasnost od neke ideje i njezinih implikacije može opravdati takav intenzitet ako je ideja predlagana od neke utjecajne osobe « (Decker, 2007, 29). Decker tu argumentira i na temelju nekih psiholoških sklonosti prosječnog čovjeka za kojeg je uobičajeno preuveličavanje problema, posebno ako je riječ o stvarima visoke i egzistencijalne važnosti. Puno je vjerojatnije da su bastioni pravovjerne misli napadali heretičke grupe toliko često, ne zbog njihove proširenosti, nego zato što su njihove ideje smatrali egzistencijalno opasnima za obične vjernike u kršćanskim zajednicama koji nisu imali potrebna sredstva za uzvratiti na takve napade, te ih je onda riječ pastira čuvala od njihovih zasjeda (Kruger i 
Kostenberg, 2010, 62). S druge strane, Bauer ne interpretira takav diskurs konzistentno. Drugim riječima, na onim mjestima gdje njegovoj teoriji ne odgovaraju slični primjeri pribjegava tezi o retoričkom triku ili osporavanju izvora, izbjegavajući zaključiti kako je i tu riječ o statističkoj varijabli. Primjerice, opasku jednog od najžešćih kritičara pravovjernog kršćanstva grčkog filozofa Celza (Origen 1965, 310) o „mnogobrojnosti Velike Crkve“ Bauer vidi kao vjerojatno lažnu informaciju zaključujući kako Celzo sigurno nije bio u poziciji kvalitetnog ocjenjivanja rasprostranjenosti Velike Crkve (Bauer, 1971, 216). Čini se da se Bauer u preslagivanju svojih ideja služio onom opaskom: »Ako dokazi ne idu u prilog tezi, to gore po dokaze.«

Sve u svemu, Bauerova analiza ranokršćanskih zajednica u Maloj Aziji ne ulijeva povjerenje. Kritičko vrednovanje njegovih teza pokazuje kako se njemački teolog nije ispravno koristio dostupnim izvorima te kako je, unatoč tomu što se predstavljao kao neovisan arbitar koji stoji između heretika i pravovjernika, prečesto postojao apologet heretika - štoviše njihov gorljivi pristaša $i$ zastupnik (Hartog, 2015, 11). Robinson zaključuje:

Bauerova rekonstrukcija povijesti rane Crkve u zapadnom dijelu Male Azije je puna pogrešaka. [...] Konačno i najvažnije, nije uspješno pokazano kako je hereza bila toliko rasprostranjena koliko je Bauer pretpostavljao. U svjetlu svih tih slabosti, Bauerova se rekonstrukcija ranog kršćanstva u Maloj Aziji mora staviti po strani (Robinson, 1985, 115).

\section{Zaključak}

Pokušavajući odgovoriti na pitanje zašto se pravovjerna Crkva uspjela nametnuti kao najdominantnija struja kršćanstva, Bauer odgovor traži u političkoj borbi i snazi Rima, koji je za njega jedini bastion pravovjerja. No, time u potpunosti promašuje širi kontekst odnosa gnosticizma i pravovjerne Crkve. Bauer ne predstavlja gnosticizam u prikladnom okviru i opsegu, zanemaruje neke njegove ključne karakteristike, pronalazi tragove gnosticizma ondje gdje ga nema i shodno s time dolazi do potpuno krivih zaključaka. Vezivno tkivo koje čini gnostičku zajednicu zajednicom utemeljeno je na snažnom antikozmičkom dualizmu, negativnom portretu Boga Starog zavjeta i temeljnoj ideji spasenja putem tajnog znanja. Sve iznad toga obilježeno je heterogenošću koja nikad nije dopustila gnosticima da se razviju u jedinstvenu zajednicu. S pravom se zato i govori o gnosticizmu kao konglomeratu nepovezanih škola (Kostenberg i Kruger, 2010, 59). Neki autori, upravo zbog radikalne različitosti, sumnjaju u ispravnost termina gnosticizam (Williams, 1996, 51; King, 2005, 15). Takve se škole također, uzmemo li širu sliku u obzir, nisu uspjele uklopiti u filozofski kontekst helenističke kulture. Naime, pravovjerno se kršćanstvo, radikalnim Pavlovim pristupom, otvorilo helenističkomu svijetu. Time kršćanstvo izlazi iz »religiozno-nacionalnih okvira židovstva i stupa u izravnu komunikaciju s poganima bez posredničke uloge starozavjetnih obreda običaja i zakona i odredbi koji su za kršćane iz židovstva predstavljali stanovitu pripravu na događaj punine koji se zbio u Isusu 
Kristu « (Bodrožić, 2012, 13). Grčka je filozofska misao u antici pronalazila argumentacijske puteve do Boga, odnosno Jednog Principa, pri čemu je politeizam za brojne grčke filozofe reduciran na stanovitu vrstu folklora. Pravovjerna se Crkva od samih svojih početaka, a posebno tijekom 2. stoljeća eksplicitno odlučila za priklanjanje grčkoj filozofiji, a ne poganskoj religiji, odbivši tako postati samo jedna od brojnih čuvara politeizma. Rana je Crkva, »odbacila kozmos antičkih religija s njihovim mitološkim predodžbama i kao svoga Boga prepoznavala je jedino onaj bitak koji su filozofi istakli kao temelj svega bića, kao najprikladniji izraz božanskog « (Bodrožić, 2013, 14). Bio je to svojevrstan susret pravovjernog kršćanstva s grčkim logosom, što je za posljedicu imalo demitologizaciju svijeta i religije. Nasuprot pravovjernomu kršćanstvu stajao je tako gnosticizam, koji svoje ishodište nije pronašao u tradiciji grčke filozofije. Umjesto toga, gnostici se odlučuju fokusirati na razvijanje kompleksnih mitoloških priča o nastanku svijeta, raznim eonima i božanskim figurama koje stanuju na različitim razinama božanskog svoda. Takav je religijski sustav ipak bio lišen stvarnih metafizičkih elemenata vrijednih pozornosti šire javnosti. Osim toga, on je u svojoj srži ahistorijski, slabo poznaje kulturu Palestine te se time i njegovi pokušaji iznošenja prave istine o Isusu iz Nazareta čine uzaludnima. ${ }^{23} \mathrm{U}$ borbi ideja i teoloških vizija, mitos je bitku za bitkom gubio, a pravovjerna se Crkva u tom kontekstu, za razliku od gnostika, odlučila za spoj objavljene istine i grčkog logosa. Stoga zasigurno i u tome treba tražiti razloge premoći Velike Crkve, koja će osim dosljednosti nauka uskoro ostvariti i statističku premoć.

\section{Literatura}

\section{Primarna literatura}

Origen (1965). Contra Celsus. U: Henry Chadwick, Origen: Contra Celsum. Oxford: Oxford University Press.

Eusebius (1981). Ecclesiastical History. U: Joseph Defferari (ur.), The Fathers of the Church. Washington D.C.: The Catholic University of America Press.

Irenaeus (1997) Adversus Haereses. U: Carol Harrison (ur.), The Early Church Fathers. London: Routledge.

Justin (2012). Apologije. Prijevod Branko Jozić. Split: Verbum.

Ignacije Antiohijski (2010). Pisma. U: Ivan Bodrožić (ur.), Apostolski oci I.: Ignacije Antiohijski: Pisma: Polikarp: Poslanica Filipljanima: Polikarpovo mučeništvo. Zagreb: Verbum.

Polikarp (2010). Poslanica Filipljanima. Ivan Bodrožić (ur.), Apostolski oci I.: Ignacije Antiohijski: Pisma: Polikarp: Poslanica Filipljanima: Polikarpovo mučeništvo. Zagreb: Verbum.

Plato (2006). Cratylus. U: Benjamin Jowett (ur.), Plato: Cratylus. Echo: Echo Library

Tacit (2006). Anali. U: Jelena Hekman (ur.), Grčki i rimski klasici: Sabrana djela Kornelija Tacita. Zagreb: Matica hrvatska.

23 Recentne komparativne analize imena koja se spominju u gnostičkom Judinu evanđelju s najpopularnijim imenima u Palestini tijekom 1. stoljeća nesumnjivo ukazuju na nepoznavanje područja o kojem se piše. Vidi primjerice u: Bauckham, 2006, 47-63. 


\section{Sekundarna literatura}

Bauer, Walter (1971). Orthodoxy and Heresy in Earliest Christianity. Philadelphia: Fortress Press.

Bingham, Jeffrey (2006). Development and Diversity in Early Christianity. Journal of the Evangelical Theological Society, 49, 45-66.

Bodrožić, Ivan (2013). Svjedočanstva vjere. Split: Crkva u svijetu.

Decker, Rodney J. (2007). The Rehabilitation of Heresy: 'Misquoting' Earliest Christianity. Bible Faculty Summit, 1-48. URL: http://www.ntresources.com/blog/documents/ EhrmanCritique_BFS_07.pdf (30.03.2017.)

Ehrman, Bart (1993). Orthodox Corruption of Scripture: The Effect of Early Christological Controveries on the Text of the New Testament. Oxford: Oxford University Press.

Ehrman, Bart (2003). Lost Christianities: The Battles for Scripture and the Faith We Never Knew. Oxford: Oxford University Press.

King, Karen L. (2005). What is 'Gnosticism'. Cambridge: Belknap Press.

Hartog, Paul A. (2015). Orthodoxy and Heres in Early Christianity. Eugene: Pickwick Publications.

Jenkins, Philip (2001). Hidden Gospels: How the Search for Jesus Lost Its Way. Oxford: Oxford University Press.

Köstenberg, Andreas J.; Kruger, Michael J. (2010). The Heresy of Orthodoxy: How Contemporary Culture's Fascination with Diversity Has Reshaped Our Understanding of Early Christianity. Wheaton: Crossway.

Markschies, Cristoph (2003). Gnosis: An Introduction. Edinburgh: Bloomsbury T\&T Clark.

Pavić Juraj; Tenšek, Tomislav Z. (1993). Patrologija . Zagreb: Kršćanska sadašnjost.

Petrement, Simone (1990). A Separate God: The Origins and Teachings of Gnosticism. San Francisco: HarperSanFrancisco.

Robinson Thomas A. (1985). Orthodoxy and Heresy in Western Asia Minor in the First Christian Century: A Dialogical Response to Walter Bauer. Hamilton: McMaster University Press.

Robinson James M; Koester, Helmunt (1971). Trajectories through Early Christianity. Eugene: Wipf \& Stock Pub.

Smith, Carl B. (2004). No Longer Jews: The Search for Gnostic Origins. Peabody: Hendrickson Publishers.

Šagi-Bunić, Tomislav J. (1976). Povijest kršćanske literature: 1. Zagreb: Kršćanska sadašnjost.

Trebilco, Paul (2006). Christian Communities In Western Asia Minor Into The Early Second Century: Ignatious And Others As Witnesses Against Bauer. Journal of the Evangelical Theological Society, 49, 17-44.

Turner, Henry Ernest William (2004). The Pattern of Christian Truth: A Study in the Relations between Orthofoxy. Eugene: Wipf \& Stock Pub.

Williams, Michael A. (1996). Rethinking 'Gnosticism': An Argument For Dismantling A Dubious Category. Princeton: Princeton University Press. 
An Analysis of Walter Bauer's Theory on the Development of Early Christianity in Asia Minor

\author{
Ivan Bodrožić*, Marko Marina**
}

\title{
Summary
}

The authors of the article discuss Walter Bauer's theory on the beginnings of Christianity in Asia Minor. Through an analysis of primary sources and modern literature, they determine the fallacies of Bauer's argumentation. Thus, Bauer's theory on gnosticism as a route taken by Christianity, prevalent during the first two centuries in the Asia Minor region, is carefully scrutinized. Errors occured, the authors conclude, due to an incorrect approach to the interpretation of sources, and hence a faulty reconstruction of the development of early Christianity in the region in question.

Key words: Walter Bauer, early Christianity, gnosticism, Orthodoxy, Asia Minor

* Associate Professor Ivan Bodrožić, PhD., Catholic Faculty of Theology. Address: Vlaška ulica 38, 10000 Zagreb, Croatia. E-mail: ivan.bodrozic@gmail.com

** Marko Marina mag. hist. et mag. educ. hist. E-mail: markomarina777@yahoo.com 